\title{
EXAMINATION OF THE MOTIVATION FOR FURTHER EDUCATION AMONG HUNGARIAN HIGH SCHOOL STUDENTS IN VOJVODINA
}

\author{
Boglárka KINCSES ${ }^{\mathrm{a}}$, Sándor PAPP ${ }^{\mathrm{b}}$
}

\begin{abstract}
${ }^{a}$ Ph.D. student, University of Szeged, Doctoral School of Geosciences, Department of Economic and Social Geography, Egyetem utca 2, H-6722 Szeged, Hungary, boglarka.kincses@geo.u-szeged.hu b Ph.D. student, University of Szeged, Doctoral School of Geosciences, Department of Economic and Social Geography, Egyetem utca 2, H-6722 Szeged, Hungary, papp_sandor_geo@geo.u-szeged.hu
\end{abstract}

Cite this article: Kincses, B., Papp, S. (2020). Examination of the motivation for further education among Hungarian high school students in Vojvodina. Deturope, 12(3): 151-168.

\begin{abstract}
The study focuses on the higher education choices of Hungarian-speaking students studying at Serbian high schools in Vojvodina. Due to the disorganized nature of Hungarian-language higher education in Serbia, Hungarian students have little opportunity to study in their mother tongue at state universities and colleges. A questionnaire was distributed among 442 students at 11 high schools in Vojvodina to find out about their intention to study after high school, their reasons for and against higher education in Serbia, and the reasons influencing their choice of higher education institution. The results were analyzed with frequency tables and word clouds. Eighty percent of respondents said they planned to continue their studies after high school. Of those, $72 \%$ would like to study in one of the Hungarian higher education institutions, while $25 \%$ would like to study in Serbia. Our results showed that for Hungarian high school students in Vojvodina, language is the most important reason when choosing a higher education institution, in terms of both a lack of knowledge of Serbian language and a desire to conduct their studies in their mother tongue. Other influencing reasons were favorable academic programs, future career opportunities, and geographic proximity.
\end{abstract}

Keywords: Hungarian language, Serbian language, Vovjodina, Higher education, School choice

\section{INTRODUCTION}

The Autonomous Province of Vojvodina is the only historical region and autonomous province of Serbia. Vojvodina is ethnically, religiously, culturally, and linguistically heterogeneous. According to the 2011 Serbian census, 67\% of the population of Serbia identified as ethnically Serbian and the remaining 33\% was constituted by almost thirty different ethnic communities. The largest ethnic minority in Serbia is the Hungarian community, representing $3.5 \%$ of the country's population. The majority of Hungarians in Serbia live in the Vojvodina region, comprising 13\% of the local population (Internet 1). The majority of Vojvodinian Hungarians live in northern Bačka (along the Hungarian border) and 
beside the Tisza River (Vojvodinian Hungarian Cultural Strategy, 2012-2018). However, the number of Hungarians in Vojvodina is steadily decreasing, mostly due to demographic (e.g., low birth rate) and other socio-economic factors (Kapitány, 2015; Palusek \& Trombitás, 2017; Šabić, 2018; Stojšin, 2015).

Among the Hungarian communities of the Carpathian Basin, the use of the mother tongue is being neglected in everyday life. As a result, assimilation processes have intensified. For this reason, it is important to give priority to Hungarian-language education in the sporadic areas (Education Development Strategy, 2016-2020). In the Hungarian scientific terminogy, the term "sporadic" is used primarily for the situation of Hungarians living in minority with other ethnic groups. This Hungarian minority live in the neighboring states as a result of the Treaty of Trianon (Bodó et al., 2007). The acquirement of the Serbian state language at an adequate level is also essential for minority, because the specialties of the ethnic environment require individuals to know the native language (Takács, 2008). For the Hungarian minority in Serbia, the mother tongue and its maintenance also mean the "subsistence" of the community. In this regard, the language of the education system plays a major role, because language is an instrument of creating and preserving community (Császár, 2011; Császár \& Mérei, 2012; Molnár, 1989).

The education laws of the Republic of Serbia guarantee the right to native-language education for national minorities in public education institutions (from nursery to high school), however students are also required to learn Serbian. The law also permits the establishment of private minority language education institutions (Internet 2). One of the criteria to start a minority language class in primary and secondary schools is to have a minimum of 15 students. Starting a class with less than 15 students requires individual approval from the Ministry of Education (Internet 3). At the level of tertiary education, the official language of education is Serbian, but the law allows courses for trainee teachers and kindergarten professionals to be taught in minority languages (Meszmann, 2001).

In Serbia, 29 pre-school institutions, 82 elementary schools and 39 secondary schools provide education also in Hungarian language. These institutions are public schools. After finishing high school, a member of the Hungarian minority has limited opportunities to continue his/her higher education studies in Hungarian language. 
Kincses, B., Papp, S.

\section{CURRENT SITUATION OF HUNGARIAN-LANGUAGE EDUCATION IN VOJVODINA}

The vast majority of education institutions in Vojvodina are public. Private and parochial schools are rare at primary and secondary level. Hungarian-language education is not independent; it is part of the Serbian education system (Gábrity Molnár, 2008).

The National Council of the Hungarian Ethnic Minority, MNT, which is the advocacy organization for Hungarian national minorities in Serbia, exercises municipal rights in education, culture, information, and minority language use (Šabić, 2018).

Hungarian-language education has several problems in Vojvodina. One of these problems is the decreasing number of Hungarian children, which can be observed across Serbia generally (Gábrity Molnár, 2008, 2018; Szügyi, 2012). Between the 2011/2012 and 2019/2020 academic years, the number of children learning in Hungarian in Serbian schools decreased by $28 \%$ in primary schools and $26 \%$ in secondary schools (Fig. 1). In addition to the decreasing birth rate, emigration and assimilation processes have impacted Hungarian families (Mikuska \& Raffai, 2018). The declining number of Hungarian children means that each academic year some schools experience uncertainty about the running of Hungarianlanguage classes. It follows that the number of primary and secondary students studying in Hungarian is also decreasing (Goran, 2015). The lack of Hungarian-speaking teachers and Hungarian-language textbooks is also problematic (Gábrity Molnár, 2008; Szügyi, 2012).

Most of the schools in Vojvodina that teach in Hungarian are bilingual (Hungarian and Serbian). In seven elementary schools and two secondary schools, the full curriculum is taught in Hungarian. In bilingual institutions, it is also frequent that, there is a Hungarian language class, but children do not learn some or all of the subjects in their mother tongue, because there are not enough teachers who can teach subjects in minority languages. Therefore, national minorities study these subjects in Serbian language (Göncz, 2006). The advantages of bilingual schools is that they can foster an interest in further education and increase students' adaptation to the labor market (Gábrity Molnár, 2008).

Serbian national law does not guarantee the right for a member of an ethnic minority to undertake higher education in their mother tongue. However, the Autonomous Province of Vojvodina passed a law in 2014 stating that minority communities have the right to education in their mother tongue at all levels of the education system, including higher education (Internet 4). Despite this, participation of national minorities in education is the least detailed in terms of higher education (Šabić, 2018). At the University of Novi Sad, there is full 
Figure 1 Number of primary and secondary school students studying in Hungarian language in Serbia

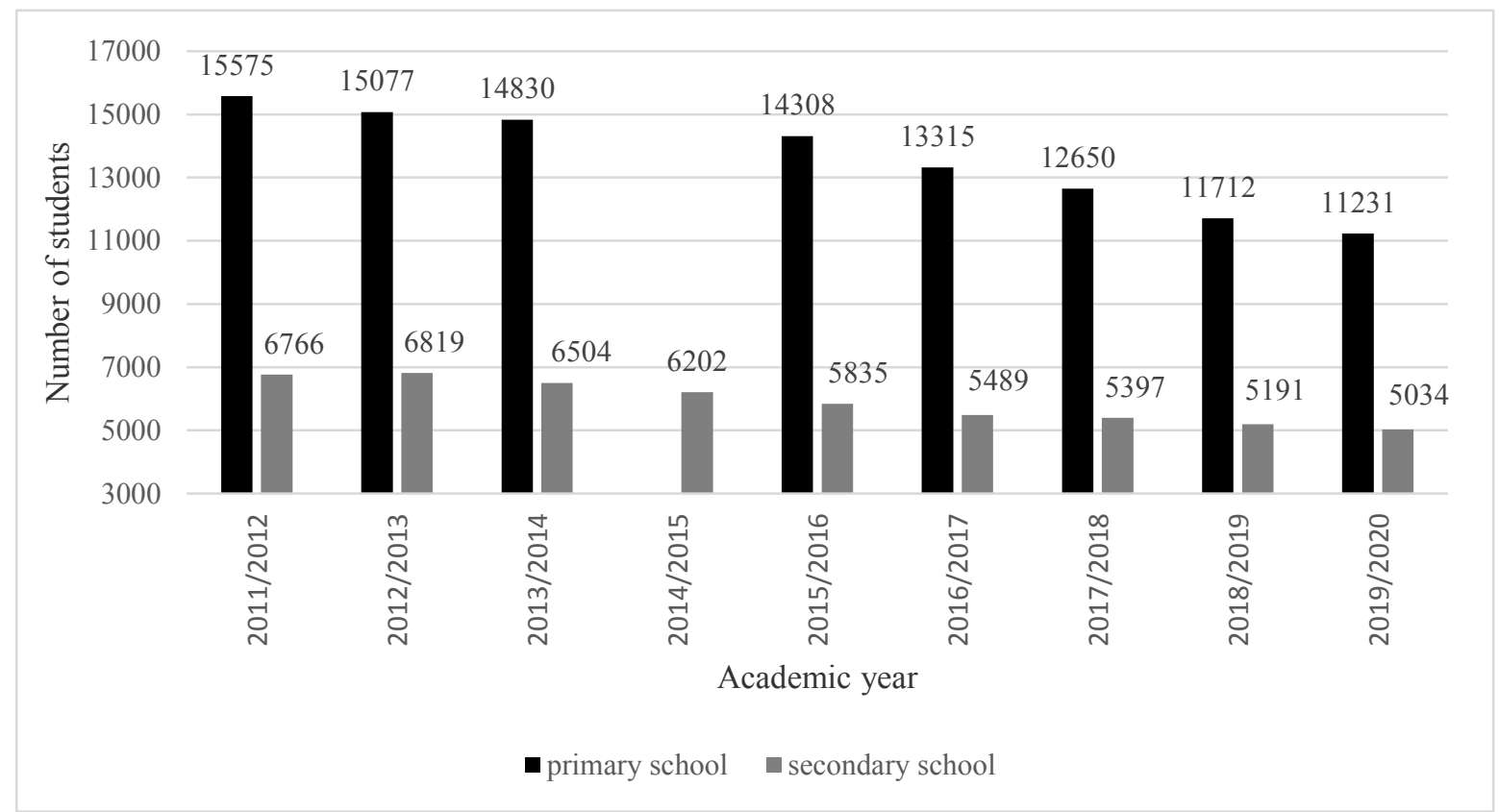

Source: Authors' construction, based on the data of National Council of the Hungarian Ethnic Minority (Note: No data is available for primary school students in the 2014/2015 academic year)

Hungarian-language training in the Hungarian Language Teacher Training Faculty (located in Subotica), the Faculty of Philosophy (Department of Hungarian Studies), and the Academy of Arts (acting specialization). The College of Applied Sciences at Subotica Tech also offers full Hungarian-language training (Takács, 2013). In addition, it is possible to study in Hungarian in the off-site training of two Hungarian universities: Zenta Consultation Center (Faculty of Horticultural Science) of Szent István University and the Sombor Training Center (Faculty of Health Sciences) of the University of Pécs, where full-time BSc nursing training in Hungarian started in September 2016 (Internet 5). At the University of Belgrade Faculty of Philology, the Department of Hungarian Language, Literature and Culture integrates the study of Hungarian language and culture, general linguistics, literature, and literary theory.

Due to the disorganized nature of Hungarian-language higher education in Serbia, Hungarian students have limited opportunities to study in their native language at state universities and colleges. The majority of Hungarian higher education students in Serbia choose to study at the University of Novi Sad or at the colleges of Vojvodina. Smaller proportions enroll at the University of Belgrade and many students go abroad to study in Hungary (Gábrity Molnár, 2008, 2019). Over the last decade, the number of Serbian citizens studying at Hungarian higher education institutions has been increasing, with some 
fluctuation. Fig. 2 shows that since 2015/2016, most Serbian citizens who study higher education in Hungary have chosen to study at the University of Szeged.

Figure 2 Number of Serbian citizens studying in Hungarian higher education institutions and at the University of Szeged in academic years 2008/2009-2017/2018

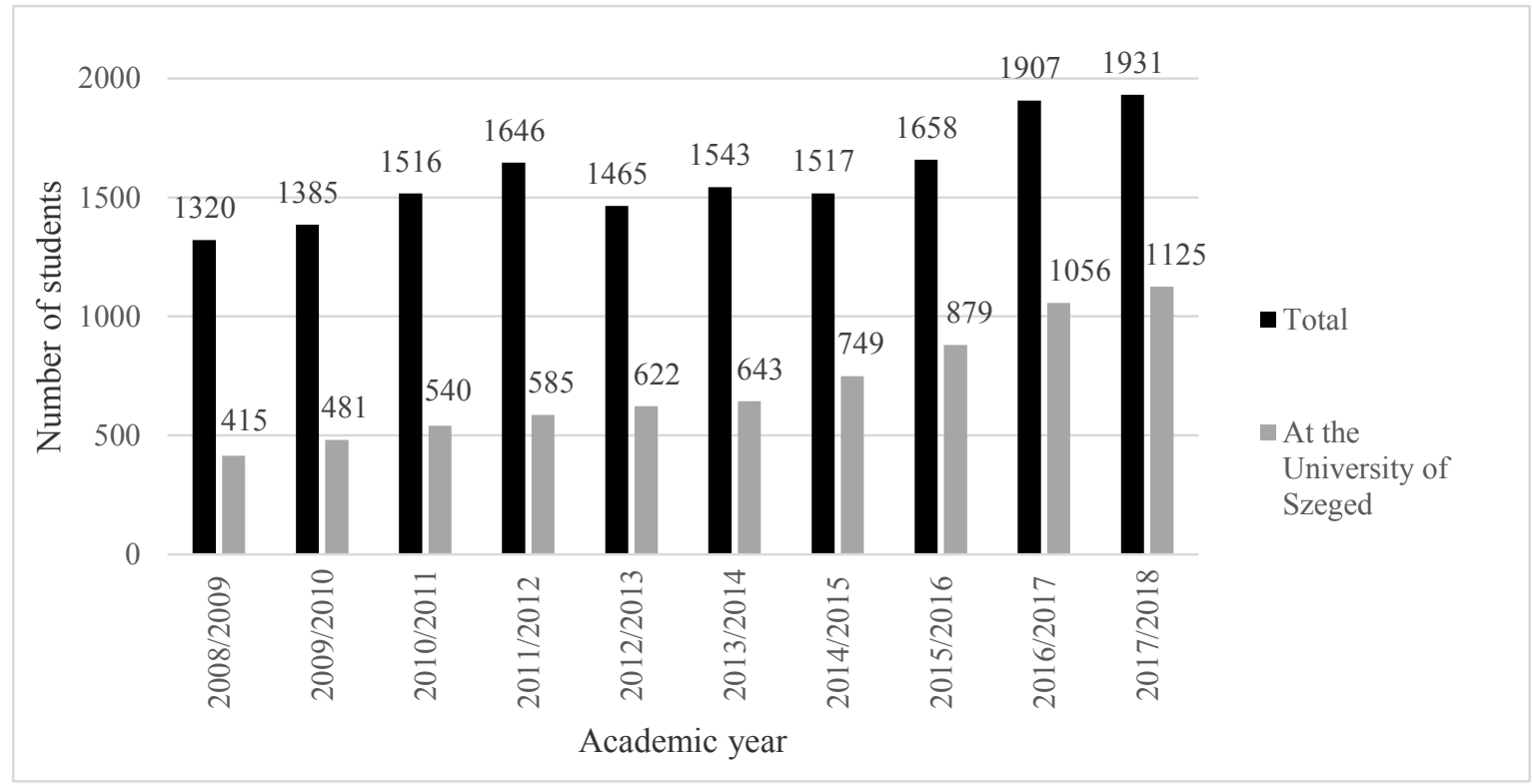

Source: Authors' construction, based on the data of the Education Directorate of the University of Szeged and oktatas.hu

The migration of Hungarian students from Vojvodina to Hungary results in significant cross-border mobility. This phenomenon has become increasingly widespread since the 2000s (Takács \& Szügyi, 2015). The main point of education migration is that the emigrant does not make a final decision about settlement, but only moves from his/her country of origin for the duration of the training. For Serbian citizens who migrate to study in Hungary, the outcome can be settling in Hungary, returning to Vojvodina, or moving to a third country (Rédei, 2009). However, research has pointed out that the majority of students from Vojvodina who graduate in Hungary do not return to Serbia, and nor do they want to (Gödri, 2005). This means a loss of qualified young people from Vovjodina, a phenomenon which has been termed "brain drain" (Gábrity Molnár \& Slavić, 2014; Takács et al., 2013). This is disadvantageous for Vojvodina, but it is a "brain gain" for the receiving country (Csanády et al., 2008; Gábrity Molnár \& Gábrity 2018). Non-return after graduation also contributes to the decrease in the number of Hungarians in Vojvodina (Palusek \& Trombitás, 2017), which endangers the long-term subsistence of the Hungarian community in Vojvodina as well as the subsistence of Hungarian-language education (Internet 6; Takács, 2012). 
MNT uses various methods to try to encourage further study in Serbia among Hungarian students, as well as trying to encourage employment in Serbia for those who obtained their higher education qualification abroad. For example, scholarships are available for young people who undertake a degree at bachelor, master, or doctoral level in Serbia. Students can apply for this scholarship if they have enrolled at any level of Serbian higher education, as well as if they have been admitted to an accredited college or academic bachelor program in Serbia. Further terms of the application stipulate that the applicant has completed his/her primary and/or secondary education in Hungarian and declares that he/she will work in Serbia for at least three years after graduation, preferably in a job corresponding to the obtained qualification.

If somebody wants to naturalize their foreign diploma, the costs of naturalization are refunded by MNT through tendering. The "Europe Dormitory" (Studentski dom "Evropa") in Novi Sad (MNT is a co-founder) offers (preferential) housing for Vojvodinian Hungarian students studying at the University of Novi Sad. The student dormitory was founded to support Vojvodinian Hungarian students' academic advancement and thus contribute to improving the general education level of the Hungarian national community living in the Autonomous Province of Vojvodina. MNT also organizes Serbian-language preparation courses for third-year high school students and students who are admitted to one of the Serbian higher education institutions. In addition, information tours are organized for secondary school students in connection with opportunities for further education in Serbia. They also focus on the promotion of talented students (talent development) (Education Development Strategy, 2016-2020).

In this study, we looked for answers to three main questions. The first question referred to the intention to pursue higher education among Hungarian high school students in Vojvodina. Secondly, among those who want to continue their studies, we examined whether they intended to study in Serbia or elsewhere, and the arguments for and against studying in Serbia. Thirdly, we enquired about students' preferred institution for higher education and the reasons that influenced their choice.

\section{DATA AND METHODS}

We collected quantitative and qualitative data to answer our research questions. From February to May 2019, a questionnaire was administered to 442 students who were learning in Hungarian at 11 secondary schools in Vojvodina (Tab. 1). Participating schools were 
selected using multistage sampling (Babbie, 2001). If a school had some classes in Hungarian, we used a paper-based questionnaire. Where there were few Hungarian language classes, we used an online questionnaire. At two schools that we invited to take part, the school director declined participation.

Table 1 List of schools who participated in the current study

\begin{tabular}{|c|c|c|c|}
\hline City & Name of the high school & $\begin{array}{l}\text { Number of } \\
\text { participants }\end{array}$ & $\begin{array}{c}\text { Type of } \\
\text { questionnaire }\end{array}$ \\
\hline Novi Sad & Medicinska škola & 26 & \multirow{8}{*}{ Paper } \\
\hline \multirow{4}{*}{ Subotica } & Gimnazija "Svetozar Marković" & 33 & \\
\hline & Gimnazija za talentovane učenike Deže Kostolanji & 56 & \\
\hline & Srednja medicinska škola Subotica & 40 & \\
\hline & Tehnička škola "Ivan Sarić" & 90 & \\
\hline \multirow{3}{*}{ Senta } & Gimnazija za talentovane učenike sa domom "Boljai" & 33 & \\
\hline & Srednja medicinska škola Senta & 63 & \\
\hline & Senćanska Gimnazija & 53 & \\
\hline $\begin{array}{l}\text { Bačka } \\
\text { Topola }\end{array}$ & Gimnazija i ekonomska škola "Dositej Obradović" & 34 & \multirow{3}{*}{ Online } \\
\hline Bečej & Gimnazija Bečej & 2 & \\
\hline Kanjiža & Poljoprivredno-tehnička škola "Besedeš Jožef" & 12 & \\
\hline
\end{tabular}

Source: questionnaire survey of the author

Responses were recorded in a digital database. We conducted crosstab analyses using Microsoft Excel 2016 and IBM SPSS Statistics 24 software to represent the values in nominal and percentage form. Word clouds were created using WordClouds.com online software. Word clouds are used to visualize the frequency of particular words in a particular text. Words are shown in a font size relative to their frequency in the text (i.e., the more frequent a word is, the larger its font).

\section{RESULTS AND DISCUSSIONS}

The questionnaire included items that assessed respondents' motivation for further study. In response to the question "Would you like to study further after high school?", $80 \%$ of respondents answered positively, $12 \%$ answered negatively, while $8 \%$ could not decide. 
Kincses, B., Papp, S.

Only those respondents who said that they would like to study further after high school (n $=354$ ) were asked the remainder of the questions, which assessed where they would like to continue their studies (both geographic location and specific institution) and what the pros and cons for studying in Serbia are. In the questionnaire, we specified 28 reasons that may have influenced respondents' choice of higher education institution.

\section{Intended location for further education}

To find out where respondents intend to study after high school, we asked "Where would you like to study further?" Slightly more than half (51\%) of respondents said they intended to study in the city of Szeged, 25\% wanted to continue their studies in Serbia, 13\% were planning to study at one of the higher education institutions in Budapest, and 8\% planned to continue their studies elsewhere in Hungary (other than Budapest or Szeged). Therefore, 72\% of those who want to continue their studies are planning to study at one of the Hungarian higher education institutions. The number of students who would like to study in another EU country was negligible at $2 \%$. Only five students could not decide where they would like to continue their studies.

Respondents were also asked about which higher education institution they would to study at. Most respondents picked more than one option. The University of Szeged was the most popular choice $(56 \%)$ for respondents who would like to study in Hungary, followed by Eötvös Lorand University (Budapest) (6\%), University of Pécs (5\%), and Semmelweis University (Budapest) (3\%). Those who want to study in Serbia were mostly interested in the University of Novi Sad (18\%) and the Subotica Tech College of Applied Sciences (10\%).

\section{Pros and cons of studying in Serbia}

We also asked the respondents about why they would like to study in Serbia and why they would not like to study in Serbia. The answers to this open-ended question were inserted into the word cloud generator.

Fig. 3 shows the word cloud generated for respondents' reasons for wanting to undertake further study in Serbia. The question was "Why do you want to study further in Serbia?" The main arguments for further education in Serbia can be summarized as attachment to the home country and subsequent career building opportunities. Some of the responses given were "I was born here and belong to this ...", "I would like to live my life here", "I would like to work at home after finishing high school", and "My future is grounded here". Their subsequent 
Figure 3 Word cloud depicting the most common arguments for studying in Serbia $(n=86)$

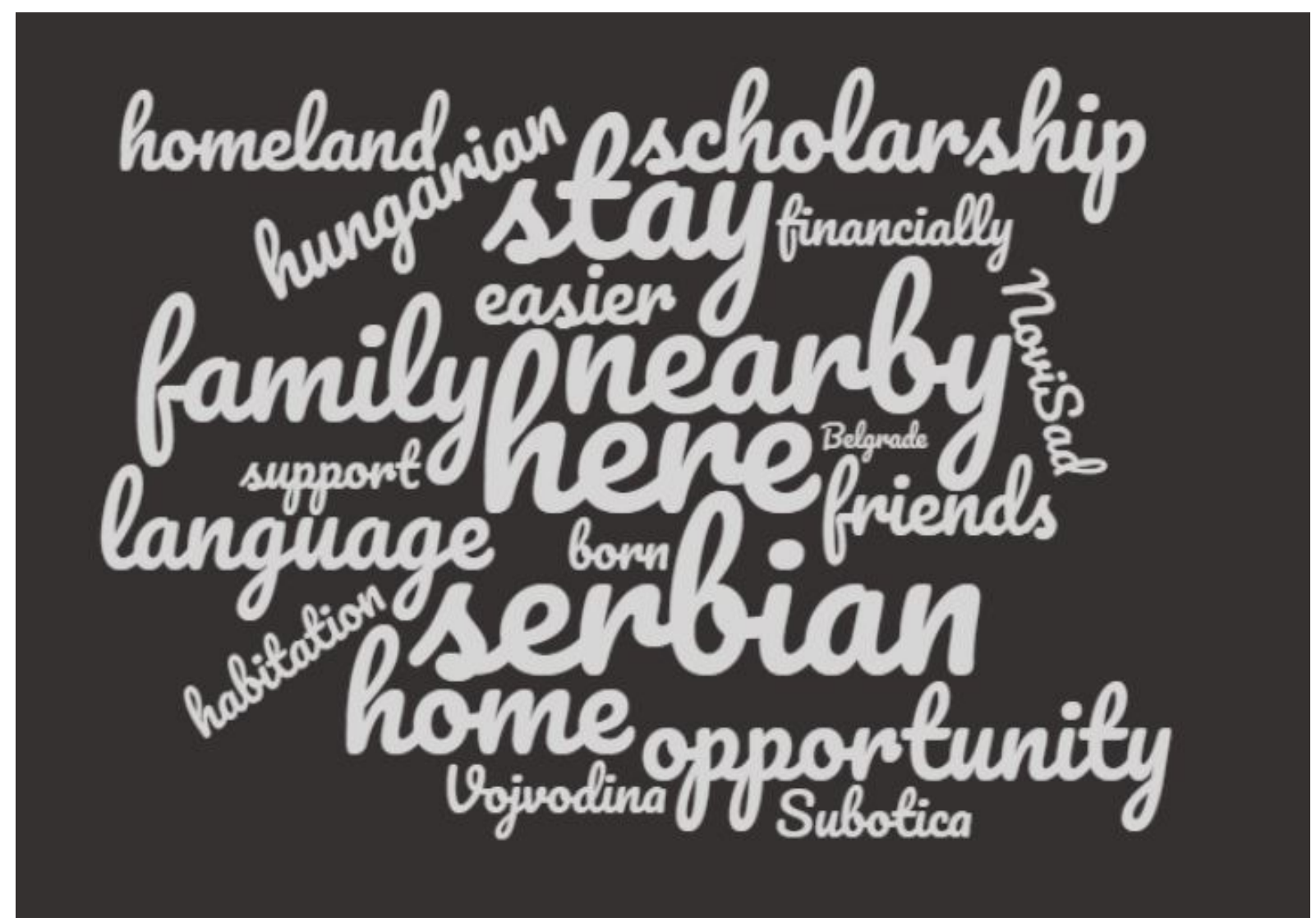

Source: questionnaire survey of the author

career building opportunities were closely related to Serbian language skills. The official language of Serbia is Serbian, which means that the use of Hungarian language is limited. Hungarian language is often pushed into the private sphere, while Serbian language dominates the official sphere and is also used in the private sphere among mixed families and friends (Gábrity, 2012; 2013). Most of the respondents speak in Serbian, so they did not see it as a problem to learn in Serbian: "Serbian language is not a problem for me, I don't feel it is important to study in Hungary", "Serbian language is easier for me than the Hungarian", and "I speak Serbian well". Other respondents do not speak Serbian at a sufficient level, and they wanted to deepen their Serbian language skills while pursuing their higher educational studies: "I think it is important that if I want to work here, I have to learn Serbian language well" and "I want to learn more about Serbian language". Staying home is also strengthened by the fact that ... "here are my friends, my family, my acquaintances". Geographical proximity was also a dominant argument among respondents: "It is close to my home, my friends. If I have a problem, I can go home easier and faster" and "It is close and I don't have to travel much". Many respondents mentioned the higher education scholarship program of MNT as an attractive factor. 
Fig. 4 shows the word cloud generated for respondents' reasons for not wanting to undertake further study in Serbia. The question was "Why do not you want to study further in Serbia?" The main reason was the lack of knowledge of Serbian language and lack of opportunity to learn in Hungarian. The majority of students from Vojvodina migrate to Hungary to study because most courses in Serbia are in Serbian language, whereas in Hungary they can study in their mother tongue. For example, respondents said "I don't know the Serbian language and I can't imagine my future in this country”, "My Serbian language skills are not good enough", "Because of the low level of my Serbian language skill, my further education is hampered here", "Learning my mother tongue is more advantageous and less stressful", and "In Serbia, I feel less opportunity in fields that I like. Of the available options, education is mainly in Serbian language, which would make it harder to graduate." For Hungarian-speaking students, an unattractive aspect of Serbian universities is that they do not have a wide range of specialties: "My chosen training program does not exist in Serbia". Furthermore, career opportunities in Serbia are scarce after graduation and better employment opportunities exist in Hungary: "In Hungary, I see more opportunities connected

Figure 4 Word cloud depicting the most common arguments for not studying in Serbia $(\mathrm{n}=247)$

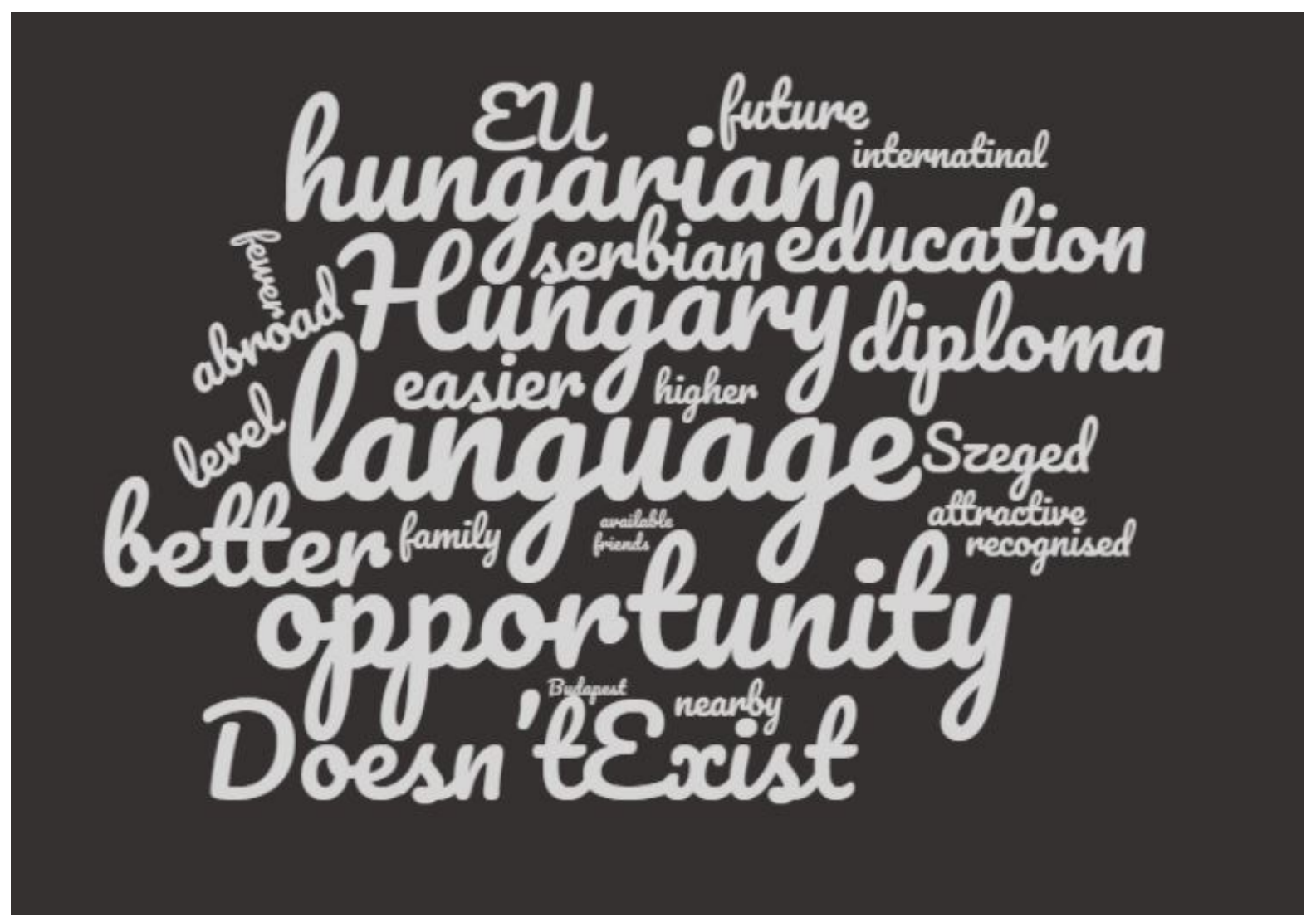

Source: questionnaire survey of the author 
Kincses, B., Papp, S.

to my future". The better marketability of the Hungarian diploma on the EU market was another attractive factor: "Serbian diploma is not an EU diploma, so with it I would only be able to find a job in Serbia". Geographic proximity and internationally acknowledged Hungarian universities appear to be other important reasons.

\section{Examination of school choice motivations}

To examine respondents' motivations for their choice of higher education institution, we collected 28 possible reasons identified in the literature (Bartha, 2014; Eröss et al., 2011; Mirnics, 2001; Takács \& Kincses, 2013; Takács, 2013; Váradi, 2013; Thelin-Niedomysl, 2015) that may have influenced their choice. We grouped these reasons into five topics: (1) personal factors and family/friendships (five items), (2) education (nine items), (3) university services, urban living, and lifestyle (seven items), (4) labor market situation and employment opportunities (four items), and (5) geographic factors (three items). On a 4-point Likert scale, respondents indicated how important each item was in their choice of institution: 1 = "Not at all" to 4 = "Fully influenced me". In addition, "Doesn't apply to me", “I don't know" and "No answer" were available as options. Table 2 and Table 3 illustrate the impact of these reasons on respondents' decision making.

First of all, we examined to what extent the reasons influenced respondents' intention to study inside or outside of Serbia. Firstly, the most important reason was linguistic competence, namely the lack of knowledge of Serbian language and lack of opportunity to learn in Hungarian. In terms of educational reasons (Tabl. 2), Hungarian-language education at their preferred institution was a fully influencing reason for $42.4 \%$ of respondents, while (the lack of) knowledge of Serbian language was considered "not at all" and "fully influencing" by a roughly equal proportion of respondents ( $24.0 \%$ vs. $21.8 \%$, respectively).

We further examined these two reasons by dividing respondents into two groups, according to where they wanted to pursue higher educational studies: Serbia or Hungary. It is notable that for that who want to study in Serbia, the lack of knowledge of Serbian language was not affected their decision (25.8\% doesn't apply to them and 32.6\% not at all affected). This suggests that those who want to study in Serbia either do not have a problem with learning in Serbian or that they found an adequate academic course that teaches in Hungarian in Serbia. For those who planned to continue their studies in Hungary, lack of knowledge of Serbian was a decisive reason $(47.7 \%)$ in their choice of institution. For them, studying in Hungarian language was considered much more important, with $49.9 \%$ saying this fully 
influenced their decision, as in the case of those who want to study in Serbia $(28.1 \%$ fully influenced).

The next most important reasons influencing respondents' choice of institution was the quality of teaching and supply of training (Tabl. 2). Respondents indicated that "The chosen training is not available in Serbia" was not a crucial reason. Responses to "In Serbia, the quality of training is inadequate" indicate that this was both an influencing and noninfluencing reason. When we divided respondents into their preferred country (Serbia or Hungary), those who want to study in Hungary indicated that inadequate quality of Serbian training was an important reason for their choice ( $49 \%$ either quite a bit or fully).

On the topic of labor market situation and employment opportunities, nearly one third of respondents answered that their choice of institution was fully influenced by their belief that they could find a job in the European Union labor market more easily (Tabl. 3). Respondents based their choice on their belief that Hungary provided better labor market conditions after graduation than Serbia $(60.7 \%$ either quite a bit or fully). It is an unattractive factor that the career opportunities are limited in Serbia, which appeared as a significant influencing factor among respondents. Almost half (48.0\%) of respondents said that limited career opportunities in Serbia influenced their choice either quite a bit or fully. Among only those students who wanted to study in Hungary, this was a major reason for their choice $(62.8 \%$ either quite a bit or fully). Serbian language skills are recognized in Hungary, but the importance of this reason was small (26.8\%). Geographic reasons did not play a very strong role in respondents' choice of institution (Tabl. 3).

On the subject of personal factors and family/friendships, $70.9 \%$ of respondents' choice of institution was fully influenced by self-interest. The presence of personal experiences ("e.g., attending open day or other university events") was a determining reason for many respondents (Tabl. 2).

Training program, good reputation, available scholarships (educational scholarship, social assistance and other scholarships such as Erasmus), and excellent student results at their chosen institution were all further influential reasons (Tabl. 2).

Although these were not mentioned as reasons for and against Serbian higher education in the open-ended answers, the availability of dormitory spaces (55.4\% either quite a bit or fully) and university student discounts (50\%) influenced respondents' choices as well (Tabl. 3). There were 11 respondents who indicated that their family has real estate in Hungary (mainly a flat in Szeged) and this fully contributed to their decision. This is a big advantage for these respondents, because housing costs in Hungary (property prices and rents) are currently high. 
Kincses, B., Papp, S.

In addition to housing reasons, the attractiveness of the city where their chosen institution is located had a high influence (67.2\% either quite a bit or fully).

Table 2 Reasons for respondents' choice of higher education institution (\%)

\begin{tabular}{|c|c|c|c|c|c|c|c|c|}
\hline & & $\begin{array}{c}\text { Not at } \\
\text { all }\end{array}$ & $\begin{array}{l}\text { Just a } \\
\text { little }\end{array}$ & $\begin{array}{c}\text { Quite a } \\
\text { bit }\end{array}$ & \begin{tabular}{|c|} 
Fully \\
influence \\
s me
\end{tabular} & $\begin{array}{l}\text { Doesn't } \\
\text { apply to } \\
\text { me }\end{array}$ & $\begin{array}{l}\text { I don't } \\
\text { know }\end{array}$ & $\begin{array}{c}\text { No } \\
\text { answer }\end{array}$ \\
\hline \multirow{5}{*}{ 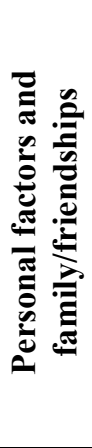 } & $\begin{array}{l}\text { Family's/relative's } \\
\text { influence }\end{array}$ & 40.7 & 36.2 & 16.9 & 2.5 & 1.1 & 1.4 & 1.1 \\
\hline & Friend's influence & 31.4 & 42.7 & 21.5 & 2.0 & 0.0 & 1.4 & 1.1 \\
\hline & $\begin{array}{l}\text { Self- } \\
\text { motivation/interest }\end{array}$ & 0.6 & 3.7 & 22.3 & 70.9 & 0.0 & 1.4 & 1.1 \\
\hline & Personal experience & 10.5 & 28.0 & 34.5 & 20.9 & 3.7 & 1.4 & 1.1 \\
\hline & $\begin{array}{l}\text { Lack of knowledge of } \\
\text { Serbian language }\end{array}$ & 24.0 & 21.8 & 16.9 & 21.8 & 12.7 & 1.7 & 1.1 \\
\hline \multirow{9}{*}{ : } & $\begin{array}{l}\text { Good reputation of } \\
\text { the institution }\end{array}$ & 8.5 & 24.0 & 48.3 & 16.1 & 0.3 & 1.7 & 1.1 \\
\hline & $\begin{array}{l}\text { Institution's training } \\
\text { program }\end{array}$ & 2.8 & 13.6 & 50.0 & 28.8 & 0.8 & 2.8 & 1.1 \\
\hline & $\begin{array}{l}\text { Hungarian-language } \\
\text { teaching in the } \\
\text { institution }\end{array}$ & 6.5 & 12.4 & 24.9 & 42.4 & 11.0 & 1.7 & 1.1 \\
\hline & $\begin{array}{l}\text { Scholarships at } \\
\text { institution (e.g., } \\
\text { Erasmus) }\end{array}$ & 4.8 & 17.5 & 44.6 & 29.1 & 0.6 & 2.3 & 1.1 \\
\hline & $\begin{array}{l}\text { Good educational } \\
\text { scholarship and social } \\
\text { assistance at } \\
\text { institution }\end{array}$ & 4.2 & 21.2 & 46.6 & 24.0 & 0.3 & 2.5 & 1.1 \\
\hline & $\begin{array}{l}\text { Excellent student } \\
\text { results at institution }\end{array}$ & 7.3 & 24.6 & 42.1 & 20.6 & 0.3 & 4.0 & 1.1 \\
\hline & $\begin{array}{l}\text { Diploma can be } \\
\text { naturalized }\end{array}$ & 17.2 & 20.3 & 22.0 & 21.8 & 11.3 & 6.2 & 1.1 \\
\hline & $\begin{array}{l}\text { Chosen training is not } \\
\text { available in Serbia }\end{array}$ & 29.9 & 4.8 & 8.8 & 15.8 & 33.1 & 6.5 & 1.1 \\
\hline & $\begin{array}{l}\text { In Serbia, the quality } \\
\text { of training is } \\
\text { inadequate }\end{array}$ & 25.1 & 13.6 & 15.8 & 20.1 & 15.0 & 8.8 & 1.7 \\
\hline
\end{tabular}

Source: questionnaire survey of the author 
Kincses, B., Papp, S.

Table 3 Reasons for respondents' choice of higher education institution (\%)

\begin{tabular}{|c|c|c|c|c|c|c|c|c|}
\hline & & $\begin{array}{l}\text { Not at } \\
\text { all }\end{array}$ & $\begin{array}{c}\text { Just a } \\
\text { little }\end{array}$ & $\begin{array}{c}\text { Quite a } \\
\text { bit }\end{array}$ & \begin{tabular}{|c} 
Fully \\
influence \\
s me
\end{tabular} & $\begin{array}{l}\text { Doesn't } \\
\text { apply to } \\
\text { me }\end{array}$ & $\begin{array}{l}\text { I don't } \\
\text { know }\end{array}$ & $\begin{array}{c}\text { No } \\
\text { answer }\end{array}$ \\
\hline \multirow{7}{*}{ 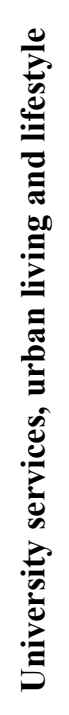 } & $\begin{array}{l}\text { Available } \\
\text { dormitory spaces }\end{array}$ & 15.0 & 19.2 & 37.9 & 17.5 & 7.9 & 1.4 & 1.1 \\
\hline & $\begin{array}{l}\text { Favorable rented } \\
\text { apartment } \\
\text { opportunities }\end{array}$ & 20.3 & 25.4 & 28.0 & 9.0 & 13.8 & 2.3 & 1.1 \\
\hline & $\begin{array}{l}\text { Family has real } \\
\text { estate in } \\
\text { Hungary }\end{array}$ & 5.1 & 0.6 & 1.4 & 3.4 & 87.0 & 1.4 & 1.1 \\
\hline & $\begin{array}{l}\text { University } \\
\text { student discounts }\end{array}$ & 15.5 & 22.9 & 35.3 & 14.7 & 6.2 & 4.2 & 1.1 \\
\hline & I know the city & 23.2 & 28.2 & 24.0 & 14.4 & 7.3 & 1.7 & 1.1 \\
\hline & $\begin{array}{l}\text { Entertainment } \\
\text { options provided }\end{array}$ & 18.4 & 28.0 & 32.5 & 16.4 & 1.7 & 2.0 & 1.1 \\
\hline & Attractive city & 10.5 & 17.8 & 38.4 & 28.8 & 1.7 & 1.7 & 1.1 \\
\hline \multirow{4}{*}{ 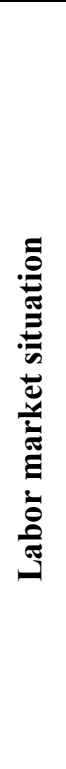 } & $\begin{array}{l}\text { Better labor } \\
\text { market in } \\
\text { Hungary after } \\
\text { graduation }\end{array}$ & 8.8 & 16.9 & 28.0 & 26.3 & 15.3 & 3.7 & 1.1 \\
\hline & $\begin{array}{l}\text { Better } \\
\text { marketability of } \\
\text { qualifications in } \\
\text { the EU labor } \\
\text { market }\end{array}$ & 11.9 & 11.3 & 29.9 & 30.8 & 10.5 & 4.5 & 1.1 \\
\hline & $\begin{array}{l}\text { Limited career } \\
\text { opportunities in } \\
\text { Serbia }\end{array}$ & 17.8 & 19.2 & 24.9 & 23.1 & 8.2 & 5.1 & 1.7 \\
\hline & $\begin{array}{l}\text { Serbian language } \\
\text { skills are } \\
\text { recognized in } \\
\text { Hungary }\end{array}$ & 19.5 & 26.8 & 20.1 & 7.6 & 4.5 & 19.8 & 1.7 \\
\hline \multirow{3}{*}{ 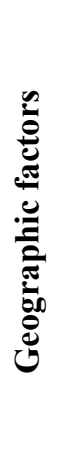 } & $\begin{array}{l}\text { Accessibility of } \\
\text { the institution in } \\
\text { terms of } \\
\text { transport }\end{array}$ & 14.4 & 32.8 & 37.0 & 11.9 & 1.1 & 1.7 & 1.1 \\
\hline & $\begin{array}{l}\text { Travel costs } \\
\text { between home } \\
\text { and institution }\end{array}$ & 19.5 & 31.6 & 34.2 & 10.5 & 1.7 & 1.4 & 1.1 \\
\hline & $\begin{array}{l}\text { Travel time } \\
\text { between home } \\
\text { and institution }\end{array}$ & 23.4 & 29.4 & 31.6 & 11.6 & 1.4 & 1.4 & 1.1 \\
\hline
\end{tabular}

Source: questionnaire survey of the author 
Kincses, B., Papp, S.

\section{CONCLUSION}

In this study, we surveyed Hungarian students studying in Serbian high schools in Vojvodina to find out about their intention to pursue higher education, their reasons for and against higher education in Serbia, and the reasons influencing their preferred higher education institution. As the migration of Vojvodinian Hungarian to Hungary for study purposes has been a complex problem for decades, its solution was not one of the aims of the article. By using the data and drawing conclusions from it, we hope we can get closer to understanding the problem.

Based on the results of our research, we can conclude that higher education in Hungary is more promising for Serbian Hungarians in the long run. Due to Hungary's EU membership, the degree obtained in Hungary is more competitive than the one obtained in Serbia. In addition, the proximity to the boundary, better livelihood opportunities, learning in Hungarian language, and the University of Szeged as a reputable university with a wide range of training, are also crucial aspects. Regardless of these attractive factors, the outcome of the process after the completion of the studies in Hungary is not one-way. Our further interview research results among Vojvodinian Hungarian students already studying at University of Szeged show that in many cases the outcome of studying in Hungary is not necessarily settling in Hungary. Many students choose to go abroad and returning to Serbia is less common.

MNT tries to encourage further study in Serbia in many ways, at the same time, the Makovecz Program, launched by the Ministry of Human Capacities (Hungary), also provides an opportunity for part-time training in Hungary for transborder Hungarian students who take part in the Hungarian teaching training at one of the higher education institutions of the neighboring countries. In the territory of Vojvodina, the University of Novi Sad (primarily its Hungarian Language Teacher Training Faculty in Subotica) and the College of Applied Sciences at Subotica Tech are member institutions. In addition, Serbia as a partner country of the Stipendium Hungaricum Programme (established by the Hungarian government), students from Serbia are able to study in Hungary and earn a full bachelor, master or doctoral degree. The future of young Hungarians in Vojvodina is highly dependent on the development of economic and social processes in the region and throughout Serbia. 


\section{REFERENCES}

Babbie, E. (2001). A társadalomtudományi kutatás gyakorlata. Budapest: Balassi Kiadó.

Bartha, Zs. (2014). Az iskolaválasztás motivációs hátterének vizsgálata Erdélyben, hangsúlyosan szórványban. Magyar Kisebbség: Nemzetpolitikai Szemle, 19(2), 60-84.

Bodó, B., Balogh, B., \& Ilyés, Z. (2007). Előszó. In Balogh, B., Bodó, B., \& Ilyés, Z. (Eds.), Regionális identitás, közösségépités, szórványgondozás (pp. 7-12). Budapest: Lucidus Kiadó.

Csanády, M. T., Kmetty, Z., Kucsera, T. G., Személyi, L., \& Tarján, G. (2008). A magyar képzett migráció a rendszerváltás óta [Hungarian skilled migration since the change of regime]. Magyar Tudomány, 169(5), 603-616.

Erőss, Á., Filep, B., Rácz, K., Tátrai, P., Váradi, M. M., \& Doris, W. W. (2011). Tanulmányi célú migráció, migráns élethelyzetek: vajdasági diákok Magyarországon. Tér és Társadalom, 25(4), 3-19. https://doi.org/10.17649/TET.25.4.1936

Gábrity, E. (2012). The intertwining of linguistic identity and ideology among Hungarian minority commuters from Vojvodina to Hungary. Jezikoslovlje, 13(2), 625-643.

Gábrity, E. (2013). A vajdasági magyar ingázók nyelvi identitása és ideológiái. Tér és Társadalom, 27(2), 118-130. https://doi.org/10.17649/TET.27.2.2522

Gábrity-Molnár, I. (2008). Oktatásunk látlelete. Újvidék: Fórum Könyvkiadó.

Gábrity-Molnár, I., \& Slavić, A. (2014). The impact of emigration from Serbia to Hungary on the human resources of Vojvodina. Zbornik Matice srpske za drustvene nauke, 2014 (148), 571-581. https://doi.org/10.2298/ZMSDN1448571G

Gábrity-Molnár I., \& Gábrity, E. (2018). Migration and language use of experts and educated population in the cross-border region of Hungary and Serbia. In Borsos, É., Horák, R., \& Námesztovszki, Zs. (Eds.), Magyar Tannyelvü Tanitóképző Kar Konferenciáinak Tanulmánygyüjteménye (pp.75-82.). Szabadka: Újvidéki Egyetem, Magyar Tannyelvü Tanítóképző Kar.

Gábrity-Molnár, I. (2018). A pályaorientáció útvesztői. In Pusztai, G., \& Szigeti, F. (Eds.), Lemorzsolódás és perzisztencia a felsőoktatásban. Oktatáskutatás a 21. században. (pp. 91-106). Debreceni Egyetemi Kiadó/Debrecen University Press.

Gábrity-Molnár, I. (2019). A vajdasági magyar fiatalok társadalmi kilátásai (közérzetmérleg). In Bali, J., Kovács, T., \& Molnár, G. (Eds.), Fiatalok a Kárpát-medencében a 21. század elején, Nemzetstratégiai Kutatóintézet és a PTE BTK 2018. október 26-27-én megrendezett II. Doktorandusz Konferenciájának elöadásait összefoglaló tanulmánykötet (pp. 100-113). Budapest: Nemzetstratégiai Kutatóintézet.

Gödri, I. (2005). A bevándorlók migrációs céljai, motivációi és ezek makro- es mikrostrukturális háttere. In Gödri, I., \& Tóth, P. P. (Eds.), Bevándorlás és beilleszkedés (pp. 69-131). Budapest: KSH Népességtudományi Kutatóintézet.

Göncz, L. (2006). Oktatásunk jövője. In Gábrity-Molnár, I., \& Mirnics Zs. (Eds.), Oktatási oknyomozó. Vajdasági kutatások, tanulmányok (pp. 125-140). Szabadka: Magyarságkutató Tudományos Társaság.

Goran, B. (2015). Impact of education in minority languages on the internal and external migrations of national minorities. (Introducing Migration in National Development Strategies). Belgrade: Swiss Agency for Development and Cooperation, International Organization for Migration and the United Nations Development Programme

Kapitány, B. (2015). Ethnic Hungarians in the neighbouring countries. In Monostori, J., Öri, P., \& Spéder, Zs. (Eds.), Demographic Portrait of Hungary 2015 (pp. 225-239). Budapest.

M. Császár, Zs., \& Mérei, A. (2012). Ethnic-homogenization processes in the most developed region of Serbia, the multiethnical Vojvodina. Historia Actual Online, 27, 117-128. 
M. Császár, Zs. (2011). The practice of Minority Education Policy in the Balkans. Revista De Historia Actual, 9(9), 125-130.

Meszmann, T. (2001). A vajdasági magyar tanügy helyzetéről. Iskolakultúra, 11(2), 7-83.

Mikuska, É., \& Raffai, J. (2018). Early childhood education and care for the Hungarian national minority in Vojvodina, Serbia. Early Years. An International Research Journal, 38(4), 378-395. https://doi.org/10.1080/09575146.2018.1479682

Mirnics, Zs. (2001). Hazától hazáig. A Vajdaságba és Magyarországon tanuló vajdasági magyar egyetemi hallgatók életkilátásai és migrációs szándékai. In Gábrity-Molnár, I., \& Mirnics, Zs. (Eds.), Fészekhagyó vajdaságiak (pp. 163-204). Szabadka: Magyarságkutató Tudományos Társaság.

Molnár, Cs. L. (1989). A magyar nyelv helyzete Jugoszláviában. Magyar Nyelvőr, 113(2), $162-175$.

National Council of the Hungarian Ethnic Minority. Education Development Strategy 20162020. pp. 68.

National Council of the Hungarian Ethnic Minority. Vojvodinian Hungarian Cultural Strategy 2012-2018. pp. 244.

Palusek, E., \& Trombitás, T. (2017). Vajdaság demográfiai és migrációs jellemzői. In Ördögh, T. (Ed.), Vajdaság I.: Vajdaság társadalmi és gazdasági jellemzöi (pp. 41-72). Szabadka: Vajdasági Magyar Doktoranduszok és Kutatók Szervezete.

Rác, L. (2008). A szerbiai oktatási rendszer finanszírozása és néhány kisebbségi vonatkozása. Regio: kisebbség, politika, társadalom, 19(2), 188-209.

Rédei, M. (2009). A tanulmányi célú mozgás. Budapest: Reg-Info Kft.

Šabić, N. (2018). A Szerbiában élő nemzeti kisebbségek oktatáspolitikai jellemzői. In Ördögh, T. (Ed.), Vajdaság II.: Variációk autonómiára (pp. 105-129). Szabadka: Vajdasági Magyar Doktoranduszok és Kutatók Szervezete.

Stojšin, S. (2015). Ethnic Diversity of Population in Vojvodina at the Beginning of the 21st Century. European Quarterly of Political Attitudes and Mentalities, 4(2), 25-37.

Szügy, É. (2012). Iskolaválasztás a Délvidéken. Kisebbségkutatás, 21(3), 514-535

Takács, Z., \& Kincses, Á. (2013). Vajdasági hallgatók Magyarországon. Területi Statisztika, 53(3), 253-270.

Takács, Z., \& Szügyi, É. (2015). Student mobility or migration flow? The case of students commuting from Serbia to Hungary. The Central European Journal of Regional Development and Tourism, 7(1), 120-136.

Takács, Z. (2008). A munkaerő-kompetencia és az oktatás viszonya. In Gábrity-Molnár, I., \& Mirnics Zs. (Eds.), Regionális erönlét. A humáneröforrás befolyása Vajdaságban (pp. 267-293). Szabadka: Magyarságkutató Tudományos Társaság.

Takács, Z. (2012). Regionális és határon átívelő felsőoktatási intézménykapcsolatok ÉszakVajdaságban. Educatio 21 (1), 104-122.

Takács, Z. (2013). Felsőoktatási határ/helyzetek. Szabadka: Magyarságkutató Tudományos Társaság.

Takács, Z., Tátrai, P., \& Erőss, Á. (2013). A Vajdaságból Magyarországra irányuló tanulmányi célú migráció. Tér és Társadalom, 27(2), 77-95. https://doi.org/10.17649/TET.27.2.2530

Thelin, M., \& Niedomysl, T. (2015). The (ir)relevance of geography for school choice: Evidence from a Swedish choice experiment. Geoforum, 67, 110-120. https://doi.org/10.1016/j.geoforum.2015.11.003

Váradi, M. M. (2013). Migrációs történetek, döntések és narratív identitás. A tanulmányi célú migrációról-másként. Tér és Társadalom, 27(2), 96-117. https://doi.org/10.17649/TET.27.2.2520 
Kincses, B., Papp, S.

\section{Internet references}

Internet 1: Municipalities and Regions of the Republic of Serbia, (2012). Statistical Office of the Republic of Serbia https://publikacije.stat.gov.rs/G2012/PdfE/G20122008.pdf (14.01.2020)

Internet 2: Zakon o zaštiti prava i sloboda nacionalnih manjina http://www.mnt.org.rs/kozerdeku-informaciok/jogszabalyok-magyarul (22.01.2020)

Internet 3: Zakon o srednjem obrazovanju i vaspitanju http://www.mnt.org.rs/kozerdekuinformaciok/jogszabalyok-magyarul (28.01.2020)

Internet 4: Statute of the Autonomous Province of Vojvodina (2014) Section 27 https://www.skupstinavojvodine.gov.rs/Strana.aspx?s=statut\&j=HU (22.01.2020)

Internet 5: https://felveteli.pte.hu/cimkek/zombor (24.01.2020.)

Internet 6: IDKM (2010). Migrációs szándék a vajdasági magyar egyetemisták körében [Intention of migration among Vojvodinian Hungarian university students] http://www.idkm.org/tanulmanyok/Migracios_szandek1.pdf (22.01.2020) 